City University of New York (CUNY) CUNY Academic Works

2005

\title{
Charting an Ethics of Desire in "The Wings of the Dove"
}

Phyllis E. VanSlyck

CUNY LaGuardia Community College

\section{How does access to this work benefit you? Let us know!}

More information about this work at: https://academicworks.cuny.edu/lg_pubs/100

Discover additional works at: https://academicworks.cuny.edu

This work is made publicly available by the City University of New York (CUNY).

Contact: AcademicWorks@cuny.edu 


\section{טอ.}

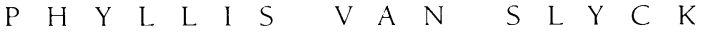 \\ Charting an Ethics of Desire in The Wings of the Dove}

Have you acted in conformity with your desire?

Jacques Lacan

We might say that the process of truth induces a subject.

Alain Badiou

WHY DO PHILOSOPHERS AND literary theorists consistently return to the question of ethical behavior in Henry James, a writer who, as Lee Clark Mitchell recently observed, "resists any simple notion of human psychology or ethical engagement"? As we struggle to understand Isabel Archer's return to her disastrous marriage, Lambert Strether's commitment to the fantasy of Madame de Vionnet, Maggie Verver's agonized contemplation of a successfully imprisoned Amerigo, and Milly Theale's construction of a space in which she can hold on to her desire, we are riveted by the complexity of these characters' emotional and ethical responses. We return to James not only because his characters' dilemmas refuse simple resolutions (perhaps any resolution) but also because we experience the suffering and paradoxical triumph of those who pursue their desire to its most far-reaching conclusion. James's characters are nothing if not willfuland ultimately alone-in their quests. Like figures from ancient Greek drama, they demand everything and give up nothing, enacting Jacques Lacan's ethical claim that "the only thing of which one can be guilty is of having given ground relative to one's desire." 2 In doing so, these characters seem to call into question, or at least complicate, the Kantian categorical imperative and the ideal of disinterested action, offering a radical ethical alternative. James's characters enact, I will argue, an ethic of desire. 
My intention here is not to reduce James's late novel to an ethical treatise but, rather, to retrieve it from a kind of situational relativism that has long been considered, from a humanist perspective, to be antithetical to ethics. A number of critics have suggested that James's protagonists engage, implicitly or explicitly, in unethical behavior, in what Sharon Cameron calls, for example, a "phenomenology of domination" as they construct fantasies of others that match their private desires. ${ }^{3}$ In keeping with Lacan's purposeful antihumanism, I will argue in contrast that James's characters pursue their desires in a way that leads to the discovery and enactment of a personal ethic, an ethic that challenges the illusory notion of the coherent subject. ${ }^{4}$

Refusing to cede one's desire leads to an awareness of the void around which reality is structured, what Lacan frames as "the Real." For Alain Badiou, as for Lacan, our normal lives are structured around the repression of the Real, and access to our subjectivity can occur only through an essential encounter, an event that "punches a hole" in the "instituted knowledges of the situation." ${ }^{6}$ Badiou argues, following Lacan, that the individual emerges as an ethical subject by holding fast to the particular truth that arises from such an Event. ${ }^{7}$ This encounter offers a foundational moment for ethical action, because the individual who is wholly committed to her desire comes into being as a subject-not the illusory coherent subject of humanism, but the shattered subject who has encountered her finitude. Lacan's and Badiou's grounding of ethical behavior in the emergence of subjectivity is especially relevant to James, for, consistently, as the characters of the late novels and tales pursue the beast in their respective jungles, they come to see that the promise of desire-personal fulfillment, coherence of the self-is an empty space. ${ }^{8}$ Why is confronting finitude the basis for an ethical position? Because it allows the individual to begin (to act) from a wholly subjective orientation, in opposition to "the reality that commands and regulates."

In The Wings of the Dove, "the great smudge of mortality across the picture" that Milly apprehends almost from her first appearance on the scene may be understood as an intrusion of the traumatic Real, ${ }^{10}$ because it serves as a kind of rupturing event, "something which turns [her] symbolic universe upside down and leads [her] to reconfigure it." ll Milly's response to her death sentence constitutes what James refers to in his preface as "the insurpassable activity of passionate, of inspired resistance." 12 From the moment she gazes at the Bronzino and tells Lord Mark, "I shall never be better than this"' (144), Milly understands that she "must pay any price for access to desire," and that "the hero[ine] trembles before nothing, especially not before the good of the other." 13

I propose that we imagine a series of ethical moves through a reading of The Wings of the Dove, borrowing Badiou's notion that poetry can assume certain of philosophy's functions: "at the very locus where philosophy falters a poem is a locus of language wherein a proposition about being . . . is enacted."14 I suggest that we begin by reconsidering Socrates's question (as Martha Nussbaum so 
beautifully framed it in her seminal philosophical discussion of The Golden Bowl ${ }^{15}$ ), "How shall we live?" from the point of view of the individual (or character) who refuses to cede her desire. Perhaps more than any other character in James, Milly Theale enacts this ethic. Despite her seeming passivity, she is placed from the beginning of her story in a terrifying battle with her mortality, and she poignantly embraces the void upon which her subjectivity must be founded. Milly's emerging ethic, however, is not based solely on the fact of her imminent doom, but on the choices she makes in dealing with this knowledge-specifically, her decision to hold fast to her desire, fully aware of the way her every gesture forces her to confront the intimate relationship between desire and mortality. ${ }^{16}$ Milly's ethic will also be explored in a broader sense as we examine the effect of her actions on her antagonists-actions that will create a moment of ethical rupture for them.

\section{II}

From the standpoint of traditional ethics, The Wings of the Dove has long been read as a study of desire and betrayal, as critics and philosophers from Millicent Bell to Robert B. Pippin have examined Kate Croy's and Merton Densher's violation of Milly Theale. ${ }^{17}$ Milly's "tragic beauty," her rueful acceptance of meanings imposed by others, and her "self-definition through opposition, resignation, or transcendence" have been thoughtfully explored. ${ }^{18}$ Her antagonists' failure to treat her as a subject has been contrasted to Milly's ethic of generous love, offering readers a neat binary between good and evil, but one that obscures the powerful dimension of desire in shaping each of these characters' responses to their respective destinies. ${ }^{19}$ For Kate, for Densher, and for Milly, an ethical moment arises that forces the question, demands that they make a decision: to abandon all or to remain faithful to their desire. According to Alenka Zupančič, such an ethical moment "makes us ask, will I act in conformity with what threw me out of joint; will I be able to reformulate what has hitherto been the foundation of my existence?"20

In this context, perhaps we have not fully seen Milly Theale: we have not understood the ethical nature of her position; that is, we have failed to grasp her insight into the power of desire, its capacity to help her imagine herself as a (shattered) subject. ${ }^{21}$ Milly actively confronts her mortality in almost every scene, and she builds her ethic by seizing and holding fast to her desire in the face of its impossibility. Early in the novel, when Sir Luke Strett confirms her fear that she does not have long to live, Milly transforms her terror into an opportunity: "The beauty of the bloom had gone from the small old sense of safety-that was distinct: she had left it behind her there for ever. But the beauty of the idea of a great adventure, a big dim experiment or struggle in which she might, more responsibly than ever before, take a hand, had been offered her instead" (162). In the days 
following her doctor's revelation, Milly sees herself as entirely alone ("nobody in the world knew where she was") yet, paradoxically, at one with other "anxious wanderers" in this "grim breathing space" (163). Her connection to another tragic heroine who knows she is doomed may clarify the nature of her position. Like Antigone, Milly confronts a "catastrophe" that is already "determined" and she knows it. ${ }^{22}$ For Lacan, Antigone's ethical "splendour" emerges through her sustained commitment to her desire, even though she knows that "her race is run ... that she advances toward nothing." ${ }^{23}$ If Milly enacts the allegory of sacrifice, that of the pharmakos or scapegoat who must be expelled, who must die for the community to heal, she transforms this ancient gesture into its postmodern counterpart, following desire beyond the limit until she enters the space in which it is purified, emptied of content; she becomes, thereby, a true "being for death." ${ }^{2+}$

On one level every character in The Wings of the Dove, quite convincingly, pursues his or her desire. But if Milly, like Antigone, remains true to her real desire, her antagonists, like Creon, pursue all that masquerades as desire but really reflects its suppression. Kate (with Densher reluctantly in tow) founds her notion of desire and fulfillment on a presumed fullness of being (a coherence) to be derived from the goods of the world: if she can acquire money and social status (along with Densher), the void will be filled. But traditional ethics, as Lacan argues, substitutes what you are supposed to do for the truth of desire, and an ethic founded on "the order of power" and the "service of goods" can only result in self-betrayal. ${ }^{25}$ Just as Creon loses from the moment he places the well-being of the state before personal desire, from the moment that Kate confuses the goods of the world for her real desire (not only for Densher but, more deeply, for her incomplete self), she is lost. The point is not merely that Kate, like Creon, has sold out; it is that she believes the desire of the Other, represented, most forcefully, by Maud Lowder, has content: that it will make her whole.

The desiring stance of each of the major characters in The Wings of the Dove is explicitly linked to this quest for wholeness, and in the opening chapters James shows how people may be led to misrecognize themselves through the lens of the social world. Each of the three major characters is initially "called into a picture" and caught in its trap: ${ }^{26}$ each, like Milly, is "photographed ... framed and glazed" (155). Where Kate succumbs to this misrecognition and Densher is paralyzed by it, Milly discovers in the gaze of the world her own mortality and, through it, the source of her desire.

In the novel's opening scene, Kate Croy examines her literal reflection in the glass over the mantel in her sister's lodgings and vows to make her beauty work for her: "If she saw more things than her fine face in the dull glass ... she might have seen that ... she was not herself a fact in the collapse" (7). Kate sets out to become the powerful, coherent "self" she believes is essential for her to succeed as she imagines doing what her father has failed to do for the family: "the broken sentence, if she was the last word, would end with a sort of meaning" (7). But Kate 
misses the connection between her own (self-) representational acts and those of her father, whom she condemns for his successful self-rendering: "the inhuman ... perfect look" (8) that has enabled him to deal out "lies" (8).

A mirror is also offered to Densher when he is invited to Mrs. Lowder's for a one-sided discussion of his relationship with Kate. And while he waits to see her, the language of her "house" speaks to him, offering him "a portentous negation of his own world of thought" (55). In response, he silently imagines how his journalistic skills might be used to undermine Mrs. Lowder's social and commercial success ("He would write about the heavy horrors that could still flourish ... in an age so proud of its short way with false gods" [54]). But when he faces her, he is quickly diminished by Maud's powerful gaze. Her silence (her refusal to engage with him in a discussion of Kate) is a "drawn blind"; "the great glaze of her surface" denies him a representation (57). Yet the emptiness Densher experiences, his recognition of literal impotence (he finds himself "in the cage of the lioness without his whip" [54]), is important because it points to the void he must understand as the essential emptiness that his desire masks.

In contrast to her antagonists, from the outset Milly recognizes that the illusion of coherence offered by the reflected image is a trap. In the Bronzino portrait, which Lord Mark takes her to see because it reminds him of her, Milly immediately perceives the way a socially sanctioned wholeness betrays its fundamental emptiness. The Bronzino shows Milly what she believes she desires, a "magnificent" completion, but the face of the woman in the portrait also contains what Lacan calls the "anamorphic blot"- that which "reflects our own nothingness in the figure of the death's head." 27 In identifying with this image, Milly simultaneously sees the impossibility, but also the necessity, of her efforts to seize her desire. Unlike Kate and Densher, Milly recognizes the paradoxical truth that she must live as if her desire is realizable even though she knows it is not. The mirror Kate uses to define herself, Aunt Maud's withering gaze, through which Densher experiences his emotional and ethical absence (his inability to defend his desire for Kate), and Milly's Bronzino, through which she recognizes the mortality of all desire, all of these "mirrors" expose the lie implicit in the struggle for coherence. For Kate, the mirror provides an illusion that she is too proud to recognize is no more than a mirage; it formulates for her a desire that is not her own but that she will cling to until she is thoroughly lost. For Densher, the emptiness of his own image reflected in Maud's gaze will force him to initiate his struggle, and as he charts his complicated course between Kate and Milly, he will construct contradictory images that chart his self-betrayal until he understands his essential lack. But for Milly, the mirror offered by the Bronzino portrait reflects, insists that she see, the void that permeates existence. "Fastened to a dying animal," she confronts her mortality in its purest form, and in recognizing the emptiness at the center of her desire, the fundamental impossibility of her dreams, she encounters her own fragile and permanently incomplete self. ${ }^{28}$ 
Before his heroine is given a place on the stage, James introduces the ethical dilemma of those who are most tied to the world, what Lacan calls the "order of power." ${ }^{29}$ As Kaja Silverman explains, "What is determinative for each of us is not how we would like to see ourselves, but how we are perceived by the cultural gaze." 30 We may infer from the way Kate is drawn ever more deeply into a compromising loss of "self" that James, like Freud and like Lacan, is deeply suspicious of the pathogenic nature of civilized morality. Even though Kate justifies her logic as she imagines retrieving her family name ("it was the name above all she would take in hand" [7]), Kate's pursuit of "fortune and honor" (5) shows the obvious dangers of an ethic tied to the cultural gaze. Like other notable Jamesian heroines (Isabel Archer and Maggie Verver), what Kate truly fears and avoids is, precisely, her desire. As Eve Sedgwick observes, "For all Kate's sharp decisiveness, she uses her high abilities to postpone, always, instead of expediting-where postponement means keeping her place in the circle of petticoats, the circuit of mediated desires." 31 But just as Milly confronts the Bronzino, recognizing the death mask it imposes, Kate also discerns the self-alienation she is engaged in as she "learn[s] in every way to express the part ... for the character she had undertaken" (217). However, in contrast to Milly, Kate represses her knowledge.

Refusing to give up the money and position that her aunt promises, bracketing her feelings for Densher and forcing him to follow suit, Kate begins to sacrifice her desire. Evidence of the problematic nature of her worldly approach to ethics is offered as she justifies her goals according to a pseudo-utilitarian model: everyone benefits-Milly will have a piece of happiness, and Kate and Densher will have her money. Despite her avowal of love ("I engage myself to you forever ... I give you every drop of my life" [66]), at no point does Kate imagine the possibility of fulfillment through Densher alone-not in a world where "fortune" counts more than self-knowledge. James makes it clear from the beginning that Kate's ethics are compromised, that something has "tampered with her spring," ${ }^{32}$ and although her poignant awareness that she is being used renders her sympathetic, James continues to emphasize the way she is consistently co-opted by those she condemns most. If Kate seems enraged at her family's fetishizing her as their only object of value ("I am on the counter when I am not in the shop window; in and out of which I'm thus conveniently, commercially whisked" [181]), she dutifully incorporates the values of these choral figures who urge her to auction herself, accepting-however ambivalently-her marketability as a valid path to the fulfillment of her desire.

Despite her willfulness, her powerful energy, and her superficial control, Kate gradually becomes the perfect surface upon which the desires of others may be registered, and her efforts to shape her destiny are consistently undermined by her selfrepresentational acts. ${ }^{33}$ In one of the few moments of "truth" for Kate-when she 
holds her own image up for critique-she warns Milly that she is not what she seems: "Oh you may very well loathe me yet!" (184). Although Kate quickly retreats from this moment of self-revelation, embracing Milly and becoming once again the heroine of the fairy tale Milly needs to believe in, Kate's facility in making this shift exposes the layered, ethically compromising function of self-representation for her: the reflected image continues to embody an escape from rather than a recognition of the fundamental "lack" that drives her desire. When Densher forces her to come to his rooms (threatening to leave Venice, and Milly, immediately if she refuses), Kate registers the distance she has traveled from him —and from her original desire. There is nothing in this moment for her: she agrees to come, not to please Densher, and certainly not for herself, but to force him to complete his task, to support the representation she has constructed to deceive Milly.

But if Kate seems to believe in the promise of an ideal social self, she implicitly concedes what she has already lost ("The way to pity me, if that's what you want, is to believe in me" [450]), she tells Densher toward the end of the novel. Like Sophocles's Creon, as Lacan describes him, she has become "dead among the living," for she has "literally lost all other goods." 34 Even Densher's final offer ("I'll marry you, mind you, in an hour" [457]) cannot alter Kate's decision: Milly's money, the excremental "gold," means more to her than the truth of her desire. The point is not so much that Kate violates the categorical imperative in her treatment of Milly (one might even argue perversely that she does not: that we would all, if dying, like to receive the gift of love-even if it is an illusion); it is that she is no longer "herself" - actually or potentially. In the end, the house of mirrors and the social order it represents, is always an empty space-and Kate gradually discovers that she has ceased to be in the picture.

However, toward the end of the novel, James simultaneously softens and complicates Kate's apparent coldness and calculation by returning her to her sister's "sordid" lodgings, where her story began, and where she is dealing with her father once again. Densher sees, ruefully, that while "he could have lived in such a place," Kate would never survive in surroundings that are "ugly to the point of being sinister" (430). In the end, Kate partially redeems herself, not because, with Densher, we feel "specially sorry for her" (430) but because she understands Milly. She may recognize, finally, that Milly's money will not make her whole; but her real insight comes from a deepening awareness of Milly's effect on Densher. When he refuses to read Milly's letter, she tells him, "You're afraid of all the truth. She died for you then that you might understand her" (456). In fact, Kate's understanding will be necessary for Densher's belated conversion to an ethic of desire.

\section{IV}

A good analyst might ask, since it is clear from the beginning that Kate is an impossible choice, what is Densher doing with her? From an ethical perspective, critics 
have focused on Densher's moral failure, his self-righteous projection of blame for Milly's death onto Lord Mark, his untenable distinction between actions and words (which even Kate in the end finds repellent), and his unconvincing conversion to Milly's love. ${ }^{35}$ Less attention has been paid to Densher's early recognition of the fundamental impossibility of his choice, confirmed not only by Aunt Maud's rejecting gaze but in numerous other instances of dissonance as he registers his incompatibility with Kate's world. Except for their one furtive meeting in Venice, Densher admits, ruefully, that he has no place to take his love; their early coming together on imagined ladders overlooking separate gardens (38) only underscores the impossibility of their ever uniting in the "real" world.

How, then, does Densher conceive of his desire? From the beginning, he is the most conflicted figure in the novel: if he believes his desire is realizable if only Kate would come to her senses, he also gradually discovers that Kate's creative and perverse arrangement of their lives, her consistent deferral, is precisely that which defines his desire, enabling him to experience "the spark of conflict ever latent in the depths of passion" (199). ${ }^{36}$ When Densher gives in to Kate's demand that he pledge himself to her but deny it to the world and pursue Milly instead, he does so believing, paradoxically, that in this way he is being true to Kate: "Not to give away the woman one loved, but to back her up in her mistakes ... that was perhaps chief among the inevitabilities of the abjection of love" (245). In response to Kate's inaccessibility, like the hero of a courtly love romance, Densher will submit to whatever test or demand his love sets for him. But the feminine object in the courtly love model is not only by definition inaccessible; she is also, according to Lacan, a metonymy for the Thing (das Ding) - "the object forever lost around which the subject and his desire revolve." 37 The darkness she embodies will gradually reveal the true nature of desire to Densher, its connection to his lack, his incompletion.

When he succeeds in convincing Kate to come to his rooms in Venice, Densher begins to understand this emptiness around which desire is constructed. Only after Kate has left Venice is Densher able to truly experience her presence: "It played for him-certainly in this prime afterglow-the part of a treasure kept, at home, in safety and sanctity, something he was sure of finding in its place when, with each return, he worked his heavy old key in the lock" (348). Densher sees, finally, that real fulfillment occurs not in the moment of passion (which is suppressed, significantly, in the text) but in the moment of recollection that follows. In his private vigil he discovers that the real object of his desire is not the elusive Kate but, rather, the "hallucination of intimacy" (348), the fantasy of something he has always already lost. But another kind of Event or intervention will be necessary for him to understand the connection between desire and loss; it will require Milly Theale.

Although some critics feel that Densher's relationship with Milly is not successfully realized, and it is true that his deepening feelings for her cannot be 
squared with his asking Kate to marry him again in the novel's closing scenes, during the period Densher remains in Venice, he begins to see Milly as a subject. Milly's impossibility, a more final impossibility than that of Kate, facilitates the final turn where Densher will discover the meaning — and the ethics—of desire. Crossing the "threshold" into Milly's Venetian palace he sees "all the elements compose differently" (315), and he knows what he must do: he executes the task of "Hermes" (James's name for him in his preface), ${ }^{38}$ guiding Milly to the Underworld. But Milly is now the "Lorelei" (also James's reference) who will draw Densher into her pool, stifling other voices with her siren song: "The unexpected impression made by pure pale, exquisite Milly as the mistress of the grand old palace ... this spectacle had for him an eloquence, an authority, a felicity for which ... he had not consciously bargained" (316). When Milly approaches the "space" where Densher keeps his memory of Kate under lock and key (she asks if she may visit him in his rooms), she directly challenges Kate's supremacy. Although Densher hesitates, there is a powerful shift in his emotions as he offers Milly Kate's "place": "He felt himself smiling through a mist ... his great scruple suddenly broke giving way to something inordinately strange... . 'You can come when you like"" (355). In this extraordinary moment of ethical "rupture," Densher sacrifices Kate for Milly, dimly discerning, but not yet fully grasping what has taken place: his "symbolic universe" has been "turned upside down," and he now begins to reconfigure it. ${ }^{39}$

In a private vigil (the reflective epiphany that is, everywhere, the moment of truth in James), Densher confronts the delicate and dangerous power of his own acts of representation, the fact that he has lied to Milly, even if only by silence and omission, and that he is now responsible for her: "He felt himself shut up in a room on the wall of which something precious was too precariously hung" (358). Ever so subtly, Densher's own identity has been incorporated into their exchange so that to betray Milly is now, also, to betray himself. Neither his early fantasy of successful textual intervention (when he imagines he will be able to write about and rise above Aunt Maud's "heavy horrors" and "false gods" [54]) nor his nostalgic imprisonment of Kate in his rooms have led him to a deeper understanding of his desire. But the "melancholy music" (316) foreshadowing Milly's death anticipates the permanent loss that will become the real object of Densher's quest: when he sacrifices Milly's letter and renders her his permanently unattainable object of desire, he encounters his own incomplete self.

\section{V}

Of the three characters, it is Milly who pursues her desire with the greatest fidelity, in a way that transforms her antagonists, and perhaps her readers. From beginning to end, Milly remains eerily separate, evincing a poignant grasp of the impossibility — and the necessity_ of her desire. From the first moment we see 
her, seated on a "precipitous" and "dizzy edge" (83) of an alpine path, ${ }^{40}$ Milly occupies a privileged ethical position. Even before she is confronted with the Bronzino, she reads her destiny in the collective gaze of the others: they "might almost terribly have suggested that her doom was to live fast" (106). In almost every reflective moment, she contemplates her absolute solitude: "no one in the world could have sufficiently entered into her state" (161); "no tie would have been close enough to enable a companion to walk beside her without some disparity" (247). But where Kate, however willful, remains until the end an actress on the stage of Maud's (and her family's) desire and an image of Densher's impossible longing (both positions in which she is the object of another's gaze), Milly pursues her desire to love and be loved in defiance of social realities she tacitly recognizes (Kate's relationship with Densher; the Lowder entourage's selfabsorbed use of her). Despite her seeming victimization, Milly is the most effective composer in the novel. Her innocent bedazzlement as she enters the London scene, seeing her surroundings, and even other people, as "touches in a picture and denotements in a play" (98), fails to conceal the way she shapes the contents of her picture according to her desire.

Milly begins by imagining other characters as if they are there for her own private purpose and use. In her initial discovery of Kate, she engages in an objectification that matches Kate's own tendency to use others for her private purpose: "She placed this striking young person from the first in a story, saw her for a heroine" (114). From the outset, Kate is someone whom Milly will be able to define according to her fantasy: "Kate had, for her new friend's eyes, the extraordinary attaching property of appearing at a given moment to show as a beautiful stranger, to cut her connexions and lose her identity, letting the imagination for the time make what it would of them" (138). This subtly aggressive compositional stance (not unlike Maggie Verver's in the second half of The Golden Bowl) expands in subsequent scenes as Milly becomes the object of Densher's desire by assuming Kate's identity, almost literally entering the physical and emotional space of her friend - in order to live (and to be loved), however vicariously, at least for a moment. With voyeuristic pleasure, Milly regards Kate "in the light of ... the identity she would have for Mr. Densher" (152). Through Kate, Milly experiences Densher's loving gaze as if it were directed toward her: "Just so was how she [Kate] looked to him [Densher], and just so was how Milly was held by herheld as by the strange sense of seeing through that distant person's eyes" (167-68). What greater evidence of her knowledge of their relationship could be offered than this gentle but purposeful acceptance of Densher's gaze as she imagines herself "embodying" Kate?

As Kate and Densher proceed with their plan, Milly apprehends their actions in such a way that their ethical duplicity may be both seen and overlooked, accepting a representation that serves her as much as it does her antagonists. Her belief in Kate and Densher is tested only to be reaffirmed when she discovers 
them together in the National Gallery. Recognizing that their presence there together betrays an intimacy they have denied to her, she nonetheless accepts (albeit uncomfortably) the composition they present: "Merton Densher was in love, and Kate couldn't help it—could only be sorry and kind ... she [Milly] tried it as a cover, tried it hard . . pulled it over her ... drew it up to her chin with energy" (194). In short, Milly continues to pursue the truth of her desire, to believe in Densher, knowing that this truth is as impossible as her own literal survival. ${ }^{41}$ In contrast to Kate's blind pursuit of completion through the socially sanctioned demands of Aunt Maud, and in contrast to Densher's struggle to imagine his fulfilled desire in the space of its absence (the memory of Kate in his rooms), Milly consciously invests both Kate and Densher with meaning, knowing that her belief in them is, in large measure, her construction.

Like Maggie Verver, who transforms herself from passive "doll" to Princess through her successive encounters with images constructed by Charlotte and Amerigo, Milly accepts the identity bestowed on her by others (such as Kate's benediction: "you're a dove" [184]), but her acceptance is far from a submission: "It was ... like an inspiration: she found herself accepting as the right one, while she caught her breath with relief, the name so given her" (184). Milly's active adoption of the "dovelike" becomes a compositional strategy that gives her the strength to control what her antagonists see, and, in effect, to transform their understanding of her, and, ultimately, of themselves. Like the ironic "trophy" Milly carries away from Sir Luke Strett, Kate's benediction is another death knell, but it is one Milly transforms through her own special alchemy: "it lighted up the strange dusk in which she lately had walked" (184). In the role of the "dove," fully conscious that she is approaching the end of her journey, Milly brings her entourage to Venice, almost literally submerging them in her watery tomb. Her friendly antagonists agree to enact her fantasy (that she will be able to remain "aloft forever"; "never going down" [292]), and she agrees not to question them. When she takes possession of her palace, "the ark of her deluge" (289), Milly seems to accept the presence of death in a new way, announcing to Lord Mark, "I think I should like to die here" (295). And when Lord Mark offers her unspecified, but seemingly irrevocable proof that Kate and Densher are engaged, Milly's fantasy space is shattered and she must confront the void. But in a sense Lord Mark confirms something she already knows: that her desire is constructed around impossibility. As Milly "turns her face to the wall" (401), she reveals the "triumph of being for death," for, as Lacan explains, the tragic heroine shows us that access to desire "necessitates crossing not only all fear but all pity." 42

Milly transforms tragedy into triumph by offering Densher, on her deathbed, and beyond her death, the gift of love: she insists on her belief in him despite the evidence of his betrayal. As Kaja Silverman explains, glossing Lacan, to give someone "the active gift of love" means to idealize the other, "to confer ideality not to find it-but to do so knowingly, and without forgetting for a moment that he or she is 
also a subject marked by lack." +3 Milly's gift transforms Densher's desire into love and initiates Densher's movement from desire to love, as Lacan describes it: "Love is distinct from desire . . because its aim is not satisfaction, but being." ${ }^{44}$ As she is dying, and after her death, Milly tacitly shows Densher how to understand his desire and his lack. She invites him to follow his desire to the place where it is empty, where he confronts her death and her loss: it is the place where pleasure becomes pain, what Lacan calls jouissance, and Densher experiences the paradoxical satisfaction of suffering. ${ }^{45} \mathrm{He}$ is summoned for a final interview, suppressed in the text but one in which he feels he has been "forgiven, dedicated, blessed" (416). Milly's forgiveness is further confirmed by her letter, even though the contents of this letter are also suppressed. But Milly's letter will enable Densher-and even, reluctantly, Kate- to understand loss as the central feature of desire, and the necessary condition for the emergence of subjectivity.

"Instead of suggesting how we should live," Mitchell observes, James's novels invite us "to respond in pity, terror, exhilaration, sheer wonder at how far outside the normal bounds these characters are subjected." 46 The ending of The Wings of the Dove offers nothing less than the kind of philosophical poetry we have been tracing, and the catharsis Mitchell describes from a reader's point of view may also be applied to James's characters' final struggle with desire, with self-knowledge, with ethical awareness. Tragedy reminds us of the need for a limit situation for the ethical subject to emerge, ${ }^{47}$ an Event that, as Badiou frames it, "compels the subject to invent a new way of being." 48 Slowly, in closing scenes of the novel, the space of reflection and recognition, we witness, through the metaphorical embrace of Milly's "wings," and through the advent of her letter, the emergence of an ethic based on fidelity to one's desire.

Thus far we have examined Kate's betrayal of her desire, her consistent privileging of the big Other, Densher's ethical crisis and partial transformation, and Milly's gift of love to her antagonists: her decision to believe in them with the knowledge of their betrayal. But in the final chapters James moves us to a more reflective place. In a sense the whole novel may be read as a movement from waiting (Milly waits to die, Kate waits for the money, Densher waits to understand) to stillness to silence, and in the penultimate scenes James uses Densher to distill the significance of the action. While he is far from a tragic hero in a classical sense, James places the act of interpretation squarely on his shoulders, and his emerging understanding is imbued with a tragic sensibility as he registers error and guilt, waste and loss, and, finally, purification and love.

When Densher returns to London, knowing Milly will soon die, he struggles to understand the two faces of desire; comparing what Kate and Milly offer him, he imagines his choices "as close as a pair of monsters he might have felt on either 
cheek" (422). He proceeds to construct two incompatible texts, one in which he and Kate are reunited; the other in which he lives with the memory of Milly. After a delay of three weeks, he meets with Kate and tells her that they must set aside all pretense and marry, that only this decisive act will make things right (419). It is as if he hopes to overcome the split in his consciousness by acting according to his original desire. ${ }^{+9}$ When Kate makes it clear, once again, that she will marry him only if he is certain they will inherit Milly's money, he begins to understand that he has never been the object of her desire, but what emerges in the novel's final scenes is much more than Densher's recognition of his "wasted passion" (421).

Beyond his guilt (which persists despite his projection of blame onto Lord Mark and even his shabby treatment of Kate), beyond his awareness of the tragic waste of Milly's life, Densher discovers his connection to Milly in the most intimate recesses of his being. His attitude toward his own desire undergoes its most radical transformation, and, ironically, it is Aunt Maud, once again, who holds up the mirror so that he may see himself - a mirror that now reflects the "truth" Densher has lived. Recollecting his final interview with Milly, and reporting it to Aunt Maud, Densher sees himself in the eyes of the other, watches himself become the person he has created for Milly: "The young man, at these moments, so seen, was too distant and too strange, for the right identity; and yet outside, afterwards, it was his own face Densher had known" (416).$^{50}$ Like Milly's adoption of the image of the dove as an emotional truth for her, Densher recognizes himself as Milly's lover. As he awaits the news of her death, he discovers that his love for Milly has become his "greatest reality" (412). ${ }^{51}$ Just as Hamlet discovers his desire (and his subjectivity) at Ophelia's grave because he experiences simultaneously his emptiness and his fullness through her loss (with the knowledge of the void upon which subjectivity rests), Densher, in contemplating the death of Milly, confronts, for the first time, his own shattered subjectivity. ${ }^{52}$

This confrontation is dramatized in what is perhaps the most poignant - and psychologically brutal-scene in the novel. Densher offers Kate Milly's unopened deathbed letter as his "sacrifice" in return for her visit to him in his rooms in Venice (his acknowledgment that she submitted to him without desire). But when Kate tosses Milly's unopened letter into the fire, she unwittingly sets the stage for his most important discovery: this irretrievable loss reveals to Densher the true nature of desire. ${ }^{53}$ It is the letter of love that has been in plain sight all along, a love that now accosts and holds Densher fast. ${ }^{54}$ Milly's gift of love, her letter and her bequest, illuminates her ethical fullness (her consistent commitment to her desire), and Densher experiences her loss as something profoundly painful ("like the sacrifice of something sentient and throbbing" [451]) but at the same time transformative, something that fulfills a new kind of longing ("he kept it back like a favorite pang; left it behind him, so to say, when he went out, but came home again the sooner for the certainty of finding it there" [450]). ${ }^{55}$ In this moment, Densher discovers his ability to give: he becomes a "father, baffled and tender" to Milly, the "maimed child" 
(450). He now stands in an authentic relationship to his desire, not because Milly now replaces Kate, thus making the lie he has lived true, but because her letter punches a hole in his established understanding: he begins to grasp the mysterious truth, that "there is nothing of significance that can fill the hole in the real." Lacan explains it, "None of the symbolic objects we invest with meaning in order to "gratify' our desire can ever be adequate"; the "work of mourning ... is performed to satisfy the disorder that is produced by [this] inadequacy." ${ }^{57}$ This powerful scene forwards Densher's movement toward ethical awareness: Milly has been elevated to the status of the permanently lost object, and even Kate understands the way Densher is altered by the Event of the lost letter. "You're afraid-it's wonderful!to be in love with her" (455).

In fact, Kate's deep intelligence permits one last ethical turn in the closing scene of the novel as she works to understand the choice Densher offers her. Accepting his claim that he was not in love with Milly while she was alive, she insists that he is now. When he asks her, finally, to choose (between him and Milly's money), she demands that he tell her he is not in love with Milly's memory: "don't speak as if you couldn't be. I could in your place; and you're one for whom it will do. Her memory's your love. You want no other" (456). Densher refuses to answer, and Kate, literally, has the last word ("We shall never be again as we were!" [457]). But if Milly's ethical stance has penetrated to the heart and transformed Densher's desire, it has also reached Kate. However self-serving Kate may sound in claiming that she and Densher have given Milly what she wanted, in the end it is she who truly understands Milly's point of view and her gift — that is, she understands the full dimension of Milly's fidelity to her desire: "She did it for us" (456). Kate articulates, in other words, what Densher only imagines, "the turn [Milly] would have given her act" (450) had they been able to read her letter, which is to say, had they been able to understand the ethics of desire.

In spite of Densher's complex struggle in the novel's closing scenes and his ultimate refusal to betray Milly-to swear to Kate that he is not in love with her memory-critics, on the whole, do not like him. It has been argued that in the end he fails to experience the self-examination that would imply a real conversion, and that his morally weak core has not changed. ${ }^{58}$ On the level of conventional ethics this may be true, but from the standpoint of an ethics of desire Densher has relinquished not only Kate but also the struggle for completion through her. He is no longer indentured to the will of others. And in his encounter with Milly's lost letter, he embraces her understanding of the necessary relationship between desire and mortality. The ethical subject, in other words, must undergo a purging of specific "objects" of desire in order to encounter "the real Thing for which these objects are imaginary substitutes." 59 This sudden insight into the abyss of Being gives way to a new kind of fidelity. It is a moment that invokes ethical behavior by calling the subject into being through what Badiou calls "the real process of fidelity to an event." 60 
And what of Milly's awareness or lack of awareness that she is being used? The notion that Milly is a naive victim who is ultimately destroyed by the "truth" - that is, her "discovery" of the real connection between Kate and Densher (through Lord Mark)_-is difficult to reconcile with Milly's consistent awareness of that relationship. While this does not lessen Kate's or Densher's responsibility, it does refocus the moral issue for Milly, who is neither naive nor a victim. Rather, she chooses to live with the knowledge that her desire for Densher, like her desire to live, is a construction-in defiance of the "facts," but necessary to her. Like Antigone, she chooses her desire, knowing it is impossible, knowing she will lose. ${ }^{61}$ In the novel's closing scenes, Milly's silence is more powerful than speech, reinforcing the unconditional nature of her gift. Although her letter has been destroyed, it has reached its destination, for it transforms her antagonists. ${ }^{62}$

Milly dies, accepting the paradoxical truth that Kate and Densher have both been, and not been, what they seemed. Just as they have literally fulfilled her desire, she fulfills theirs in bequeathing Densher her money. Milly's Bronzino, embodying simultaneously her permanence and her transience, like her unopened letter, anticipates a structure of meaning that is fulfilled by Densher's final recognition of himself as a man in mourning, not only for Milly but for himself, a man who must remain permanently in a state of lack. In these final scenes, James's characters enact a direct confrontation with the myth of coherence that they have engendered in pursuing their desire. In place of the Enlightenment model of an ethic associated with higher reason, a refinement of the "self" (a self still, therefore, connected to what Badiou calls the "anarchic debris of circulating knowledge"), ${ }^{63}$ James anticipates a view of subjectivity (and implicitly an ethic) that can come into being only through a kind of madness-a recognition of the emptiness at the heart of being.

Through their pursuit of the truth that their objects of desire mask, James's characters discover an "ethic of the Real" - what Badiou calls "the ethic of a truth." 64 In confronting permanent loss and universal lack, they experience, to different degrees, painful pleasure, preserving the authentic place of their jouissance even though the object of desire is empty. ${ }^{65}$ In this way they begin to retrieve an ethic from what appears to be a profoundly relativistic world of competing claims and designs. As Alenka Zupančič has suggested, Lacan's ethic of desire has much more in common with Kant's ethical demand that the individual act "for duty alone" than is generally recognized; she argues that in fact Kant and Lacan arrive at the same place. That is to say, the individual who pursues his or her desire to the end and comes to recognize that the object of desire is a substitute, something that blocks one's (impossible) awareness of the Real, is ultimately acting "for duty alone" or in Lacanian terms, for desire alone-stripped of its object. ${ }^{66}$ James's characters discover that the object of desire is the site of an imaginary blinding but also, potentially, the site of ethical truth: a place where the "self" and all the symbolic desires it creates to assure its coherence must eventually be recognized as an illusion. 
By discovering the truth of their desire, James's characters also discover their own in-coherent selves, their shattered subjectivity. To return to James's image of Milly as a "Lorelei" who will see her antagonists "terrified and tempted and charmed; bribed away from more prescribed and natural orbits," ${ }^{27}$ we see how Milly initially pulls Kate and Densher out of a more "natural" ethical path by tempting them with her money. But this passage may be read in an obverse way (to borrow James's image of the two-sided coin): in the end Milly invites her antagonists to abandon the "prescribed" path in order to understand the ethics of desire. Like Antigone, Milly stands for that purification of desire that is "central for access to any realization of oneself." 68 She arrives at a place where her desire is dis-interested, and therefore ethical: it has been emptied of content, and her vulnerable gift of love is all that remains. ${ }^{69}$ Densher's poignant and loving contemplation of her silence suggests that he, too, understands that Milly has successfully altered his "orbit." At the end of The Wings of the Dove we witness Densher's fidelity to the Event of Milly Theale. We also note that Kate witnesses this Event: when she tells Densher he has fallen in love with Milly, admitting she would have done so, too, in his place, she speaks a different kind of truth from that which has guided her for most of the novel-it is a truth that contains the kernel of a new ethic. Through Milly's letter, which functions as a kind of resurrection, she insists on the truth that emerges through fidelity to one's desire. She demands that her antagonists recognize her subjectivity—and through it, their own. Milly's gift of love, embodied in her ethereal presence at the end of the novel (a silent but powerful siren song), is an image of ethical action.

If poetry, as Badiou suggests, articulates our "essential disorientation . . . cut[s] open a space within historical pathos,"70 it is also, thereby, an Event that "throws us outside of ourselves" and offers a "truth" that is not a "sense" but, rather, "a hole in sense." "Il And it is Milly, in the moment of her final descent into her Venetian fortress, who most eloquently describes the status of the subject who lives "between two deaths," 72 who sees, as the tragic heroine always does, the strange and paradoxical envy of those (characters and readers) who bear witness to (but are excluded from) the purity of her ethical condition:

She couldn't have said what it was, in the conditions, that renewed the whole solemnity, but ... a kind of wistful hush had fallen upon them, as if before something poignant ... That was nothing, verily, but the perfection of the charm-or nothing, rather, but their excluded, disinherited state in the presence of it. The charm turned on them a face that was cold in its beauty, that was full of a poetry never to be theirs, that spoke, with an ironic smile, of a possible, but forbidden life. 


\section{Notes}

1. Lee Clark Mitchell, "Ethics, Aesthetics and the Case of Late James," Raritan 22, no. 4 (Spring 2003): 88.

2. Jacques Lacan, The Ethics of Psychoanalysis, 1959-60: The Seminar of Jacques Lacan Book VII, ed. Jacques-Alain Miller, trans. Dennis Porter (New York: Norton, 1992), 319. (Henceforth, this title will be abbreviated as Seminar VII.)

3. Sharon Cameron, Thinking in Henry James (Chicago: University of Chicago Press, 1989), 11. Leo Bersani initiated this line of thinking some time ago when he argued that James "would encourage us to believe that our range of experience can be as great as our range of compositional resource," that "fictional invention constitutes the self" (A Future for Astyanax: Character and Desire in Literature [New York: Columbia University Press, 1969], 132). In contrast, some contemporary critics have supported James's characters' creative composing, as I do here, because the images produced (and believed in) challenge humanist essentialism and thereby anticipate the postmodern critique of the core self. Priscilla Walton, for example, argues that James's characters demonstrate what Louis Althusser calls the "ambiguity of the subject" (Walton, "There's no such thing as an isolated man or woman': Subjectivity and The Portrait of a Lady," Connecticut Review 12, no. 2 [Summer 1990]: 96).

4. Mladen Dolar notes that "the structuralist revolution has ... seen itself as a break away from the humanist tradition centered on the subject." She explains the critique of the cogito in Lacan's early work thus: "The alternative that Lacan has in mind . . is the following: the mirror stage ... demonstrates that the I, the ego, is a place of an imaginary blinding, a deception ... it must be sharply opposed to cogito with its inherent pretension to self-transparency and self-certainty" "Cogito as Subject of the Unconscious," in Cogito and the Unconscious [Durham, NC: Duke University Press, 1998], $11,12)$.

5. The Real is "what resists symbolization absolutely" (The Seminar of Jacques Lacan: Book I, trans. John Forrester [New York: Norton, 1991], 66). As Alenka Zupančič points out, "desire can be defined as the pure form of demand when all the particular objects (or 'contents') that may come to satisfy it are removed" (Ethics of the Real: Kant, Lacan [New York: Verso, 2000], 18).

6. Alain Badiou, Ethics: An Essay on the Understanding of Evil, trans. Peter Hallward (London: Verso, 2001), 42. (Henceforth, Ethics.)

7. Throughout this essay, I will use the term "Event," with a capital E, to indicate my use of the term as Alain Badiou defines it. See Alain Badiou, Manifesto for Philosophy (Albany: State University of New York Press, 1992), 80-88. (Henceforth, Manifesto.) "To behave ethically, for Badiou, is to remain faithful to a moment of inspiration or insight and to pursue whatever line of thought and action is required to sustain this fidelity. Such disclosures of truth can occur, on his account, in four fundamental domains-politics, science, art and love. They do not transform and dynamize a preexistent knowing and acting subject. Rather, it is the irruption of an always singular truth through the tissue of everyday 'opinion' which first brings a subject-individual or collective-into being" (Peter Dews, "States of Grace: The Excess of the Demand in Badiou's Ethics of Truths," in Think Again: Alain Badiou and the Future of Philosophy [London: Continuum, 2004], 108). 
8. For Lacan, all objects of desire are a substitute for the objet petit a-the object that can never be attained and that is nonetheless the cause of desire. The symbol "a" refers to the first letter of the word "autre." It is the object of desire that we seek in the other (Four Fundamental Concepts of Psycho-analysis, ed. Jacques-Alain Miller, trans. Alan Sheridan [New York: Norton, 1978], 76-77).

9. Lacan, Seminar VII, 55. Throughout his discussion of ethics, Lacan engages in a dialogue with Kant. "It is here [in pursuit of one's desire] that, along with Kant, we must see the focal point, aim and convergence, according to which an action that we will qualify as moral will present itself' (Seminar VII, 55). I will return to this connection at the end of this essay.

10. Henry James, The Wings of the Dove (Middlesex, England: Penguin, 1965). All references to the text are taken from this edition.

11. Zupančič, Ethics of the Real, 235.

12. Preface, The Wings of the Dove (New York: Norton, 1978), 4. All references to the preface are taken from this edition.

13. Lacan, Seminar VII, 323.

14. Badiou, Manifesto, 69. It is perhaps worth noting that throughout his work, particularly in the Manifesto, Badiou acknowledges his debt to Lacan. See note 54 below.

15. Martha Nussbaum, "Flawed Crystals: James's The Golden Bowl and Literature as Moral Philosophy," New Literary History 15 (1983): 25-50.

16. "Try to imagine what 'to have realized one's desire' might mean ... all that exists lives only in the lack of being" [for] "the relationship to death supports or subtends, as the string does the bow, the curve of the rise and fall of life" (Lacan, Seminar VII, 294).

17. Bell shows us how Christian tradition informs an ethical reading: "Milly is not Christ, but James wanted to introduce the powerful vocabulary of the tradition which insists on the immeasurable value of the spirit and the ethic of generous love in the place of the modernism exemplified by Kate and Densher" (Meaning in Henry James [Cambridge: Harvard University Press, 1991], 294). Sallie Sears offers a representative formulation of the Kantian position: "In the broadest sense the novel is an anatomy of guilt; of the causes, then the consequences, of deliberate, conscious violation of another human being's existence for the sake of personal gain" (The Negative Imagination: Form and Perspective in the Novels of Henry James [Ithaca: Cornell University Press, 1968], 63). Pippin updates Sears's reading, arguing that James is interested in "one's entitlement to treatment as a free subject, to a life that is one's own ... that Milly was entitled to considerations she did not receive" (Henry James and the Modern Moral Life [Cambridge: University of Cambridge Press, 2000], 3-4).

18. John Carlos Rowe, "The Symbolization of Milly Theale: Henry James's The Wings of the Dove," English Literary History 40 (Spring 1973): 132.

19. Lee Clark Mitchell, "The Sustaining Duplicities of The Wings of the Dove," Texas Studies in Language and Literature 29, no. 2 (Summer 1987): 200. Marcia Ian, "The Elaboration of Privacy in The Wings of the Dove," English Literary History 51 (Spring 1984): 108.

20. Zupančič, Ethics of the Real, 235.

21. Ian has succinctly summarized a range of interpretations (aesthetic, moral, psychological, and philosophical), many of which underscore James's heroine's moral valorization yet consistently passive role: "Milly's triumph over physical death becomes 
an ethical conquest. ... It is not far from here to religious or allegorical readings of the novel that intensify Milly's self-resignation to self-sacrifice" (108). Leon Edel's description of Milly as "compliant and sacrificial" (Henry James: The Master, 1901-1916 [New York: Avon, 1972], 114) and a host of subsequent readings have emphasized Milly's passivity. Even James's own description of his compositional process reinforces the way others act upon Milly: "I go but a little way with the direct ... straight exhibition of Milly lapproaching her] 'circuitously' ... watching her ... through successive windows of other people's interest in her" (Preface, Wings of the Dove, 4). John Carlos Rowe seems to echo James's compositional formulation in noting that Milly finds herself "increasingly the central figure, but in someone else's composition of relations," concluding that she is "finally present only through the interpretive consciousness of others" (158). More recently, Gert Beulens summarizes this tendency to view Milly "as an essentially 'empty' quantity," arguing that she gains her hold through metonymy: "she acquires metonymical strength" by adopting the dove image, for example ("Metaphor, Metonymy and the Constitution of Identity in The Wings of the Dove," Canadian Review of American Studies 31, no. 1 [2001]: 414).

22. Preface, Wings of the Dove, 4.

23. Lacan, Seminar VII, 272, 280.

24. Ibid., 309.

25. Ibid., 314,315 .

26. Lacan, Four Fundamental Concepts, 92.

27. Ibid.

28. Milly is the emblem of modernity as W. B. Yeats imagines it-and perhaps postmodernity. Kenneth Reinhard describes the way James's novel is haunted by the "real thing," that which is both "within and beyond its representations" (139). He explains: "For death is both that which 'we cannot possibly not know,' sooner or later, and that which we 'never can directly know, since it marks the end of our knowledge, and is experienced only through the 'beautiful circuit' of thought and desire on the way to death" ("The Jamesian Thing: The Wings of the Dove and the Ethics of Mourning," Arizona Quarterly 53/54 [Winter 1997]: 138, 139).

29. Lacan, Seminar VII, 314.

30. Kaja Silverman, The Threshold of the Visible (New York: Routledge, 1996), 19.

31. Eve Sedgwick, "Is the Rectum Straight? Identification and Identity in The Wings of the Dove," in Tendencies (Durham, NC: Duke University Press, 1993), 92.

32. Preface, Wings of the Dove, 9.

33. As Julie Rivkin notes, "although Kate will look to this image both to confirm her own value ... and to redeem her family, what it gives back will always be something other than herself or her design. Far from possessing this image of herself, Kate will see it doubled and redoubled in the eyes of others" (False Positions: The Representational Logics of Henry James's Fiction [Stanford, CA: Stanford University Press, 1996], 93).

34. Lacan, Seminar VII, 321.

35. See, in particular, Charles Thomas Samuels: "Densher's stupidities and sophistries constitute a compelling portrayal of decorous evil" (The Ambiguity of Henry James [Urbana: University of Illinois Press, 1971], cited in The Wings of the Dove, eds. J. Donald Crowley and Richard A. Hocks [New York: Norton, 1978], 579); also see Sallie 
Sears: "A conversion implies a degree of self-examination and valuation (rejection of the sinful self) that never takes place in Merton ... we do not feel moved, convinced of some radical spiritual growth" (93); "Densher's sudden access to piety is accomplished with too much ease; he does not suffer enough" (97); and Bersani: "Densher's flabby reasoning allows him to move from one spiritual allegiance to another without ever disturbing the perfect stillness of his being" (Future for Astyanax, 143).

36. As Renata Salecl reminds us, "one of the greatest illusions of love is that prohibitions and social codes prevent its realization" "I Can't Love You Unless I Give You Up," Gaze and Voice as Love Objects, eds. Slavoj Žižek and Renata Salecl (Durham, NC: Duke University Press, 1996], 179). Denis de Rougement also argues in his seminal work on love, "it is romance that we revel in-that is to say, the self-consciousness, intensity, variations, and delays of passion.... What moves us is not its presence, but its nostalgia and recollection" (Love in the Western World [Princeton, NJ: Princeton University Press, 1940], 52)

37. Jonathan Scott Lee, Jacques Lacan (Amherst: University of Massachusetts Press, 1990), 164. "The function of the pleasure principle is to make man always search for what he has to find again, but which he never will attain" (Lacan, Seminar VII, 65). "The Thing is characterized by the fact that it is impossible for us to imagine it" (Lacan, Seminar VII, 125); it is that which "resists symbolization absolutely" (Lacan, The Seminar of Jacques Lacan Book I: Freud's Papers on Technique, ed. Jacques-Alain Miller, trans John Forrester [New York: Norton, 1988], 66). (Henceforth, Seminar I.) "Lacan's concept of the Thing as an unknowable $x$ beyond symbolization has clear affinities with the Kantian thing-in-itself' (Dylan Evans, An Introductory Dictionary of Lacanian Psychoanalysis [London: Routledge, 1996], 205).

38. Preface, Wings of the Dove, 10.

39. Zupančič, Ethics of the Real, 235.

40. James refers to this location in his preface as "some icy high arête" (8). One cannot resist the thought that the author plays with a double meaning here: literally, a sharp ascending ridge, and, metaphorically, an arrêt: the place that "stops" Milly in the most final sense.

41. Rivkin comments: "that ill-fitting 'cover' will allow Milly to confirm Kate's representation that Densher is available, even as it allows her to maintain her own story that life is within her grasp" (False Positions, 104).

42. Lacan, Seminar VII, 323.

43. "The active gift of love consequently implies both idealizing beyond the parameters of the 'self,' and doing so with a full understanding of one's own creative participation with respect to the end result" (Silverman, Threshold of the Visible, 78). Lacan argues that "Love is distinct from desire... Because its aim is not satisfaction but being"; "the active gift of love is directed at the other, not in his specificity but in his being"; that is to say, it is "to love a being beyond what he or she appears to be" (Seminar I, 276).

44. Lacan, Seminar I, 276. Badiou calls Lacan a "theoretician of love" when he claims, "It is love that accosts being in the encounter" ["Lêtre comme tel, c'est l'amour qui vient a y aborder dans la rencontre"] (Seminaire XX_-"Encore" [Paris: Seuil, 1975], 133).

45. An important thread in Lacan's discussion of desire emerges in his analysis of jouissance. Following Freud's analysis of the pleasure principle-specifically, the notion 
that we create prohibitions in order to transgress them and that desire is founded on the paradoxical satisfaction we derive from not being able to achieve satisfactionLacan argues that jouissance is "painful pleasure": it leads us to the death drive: we attempt to break through the pleasure principle in search of jouissance and we encounter the Thing, "the path towards death" ["le chemin vers la mort"] (Le Seminaire livre XVII: L'envers de la psychanalyse [Paris: Éditions du Seuil, 1991], 17).

46. Mitchell, "Ethics," 88.

47. Lacan defines "limit situation" as "the moment when in his tragic liberty [the hero/heroine] has to deal with the consequence of that desire that led him to go beyond the limit, namely, the desire to know" (Lacan, Seminar VII), 305.

48. Badiou, Ethics, 42.

49. In this contradictory moment, it seems to me that James mitigates one-dimensional readings of Densher; there is much that disturbs "the perfect stillness of his being"; he does not simply "surrender to the dovelike in human nature" (Bersani, Future for Astyanax, 143).

50. Bell notes, "the story enacted by his calculated tenderness has becomes true. It is his alterity" (Meaning in Henry James, [Cambridge: Harvard University Press, 1991], 309).

51. Rivkin comments: "the explicitly performative status of Densher's role with Aunt Maud does nothing to diminish his sense of its authenticity; indeed, only with Aunt Maud does Densher feel free to speak of his time with Milly, a time that comes to seem increasingly real to him" (117).

52. As Lacan suggests, "The one unbearable dimension of possible human experience is not the experience of one's own death, which no one has, but the experience of the death of another, for it opens a hole in the real which nothing can fill." That is to say, none of the symbolic objects we invest with meaning in order to "gratify" our desire can ever be adequate; the "work of mourning is ... performed to satisfy the disorder that is produced by the inadequacy of the signifying elements to cope with the hole that has been created in existence" "Desire and the Interpretation of Desire in Hamlet," Literature and Psychoanalysis: The Question of Reading: Otherwise, Shoshana Felman ed. [Baltimore: Johns Hopkins University Press, 1977], 37, 38). (Henceforth, "Hamlet.")

53. As Reinhard suggests, "Kate's expedient attempt to destroy 'the thing' by sacrificing Milly's letter has the unexpected effect of preserving it as an ultimate irreducible thing for Densher" ("Jamesian Thing," 134).

54. Badiou considers Lacan's work on love to be "an event and a condition for the renaissance of philosophy"; he also notes that "the specifically ontological function [Lacan] assigns to love clearly shows the kind of insertion he is conscious of implementing in the configurations of philosophy with respect to theories of love" (Manifesto, 82, 83).

55. It is perhaps worth noting that the structure of the action (returning to the locked room) duplicates Densher's earlier return to the single moment of intimacy with Kate, but the emphasis has shifted, for he now understands-and embraces-the irrevocability of loss.

56. Lacan, "Hamlet," 37.

57. Ibid., 39 . 
58. Sears, Negative Imagination, 97.

59. Lee, Jacques Lacan, 167.

60. Badiou, Ethics, 42. "The subject, therefore, in no way pre-exists the process. He is absolutely non-existent in the situation before the event" (43). According to Žižek, "Lacan and Badiou thus share the notion of a radical cut/rupture, 'event,' encounter of the Real, which opens up the space ... for the modality of the truth procedure" ("From Purification to Subtraction," in Think Again, 172).

61. Reinhard also notes the connection between Antigone and Milly: "Milly fashions a place for herself in the 'grim breathing-space' that opens between this symbolic mortification and the real death it anticipates. This is the realm that Lacan calls the 'between-two-deaths, 'the tragic topology ... into which it is the fate of such heroines as Antigone and Milly Theale to proceed" "Jamesian Thing,"129).

62. "[A] letter has completed its destiny after fulfilling its function" (Lacan, "Seminar on the Purloined Letter," trans. Jeffrey Mehlman in The Purloined Poe: Lacan, Derrida and Psychoanalytic Reading, eds. John P. Muller and William J. Richardson [Baltimore: Johns Hopkins University Press, 1988], 40). As Shelia Teahan suggests, "Kate's destruction of the unread letter ironically empowers it and actualizes Milly's absent mediation" ("The Abyss of Language in The Wings of the Dove," Henry James Review 14 [1993]: 208).

63. Badiou, Ethics, 50 .

64. Badiou calls the "ethic of a truth" an "ethic of the Real," directly referring to Lacan (and linking the Lacanian 'Real' to the Badiouian 'event') in noting that "all access to the Real is of the order of an encounter" (Ethics, 52). In this same passage, Badiou links his own ethical maxim, "Keep going!" [Continuer!], to Lacan's, "do not give up on your desire."

65. "This Law makes my neighbor's jouissance the point on which ... the meaning of my duty is balanced. Must I go toward my duty of truth insofar as it preserves the authentic place of my jouissance, even if it is empty? Or must I resign myself to this lie ... substitut[ing] forcefully the good for the principle of my jouissance" (Lacan, Seminar VII, 190).

66. Standing in the right relation to one's desire, therefore, for Lacan, for Badiou, and for James, means, precisely, to become dis-interested — that is, to pursue one's desire until it is emptied of content. Zupančič believes that the Lacanian "Real" is synonymous with the Badiouian "Event," that both reflect a fidelity to an ethics of truth (Ethics of the Real, 235). Žižek and Zupančič have worked to forge an important connection between Lacanian and Kantian ethics, (Zupančič, Ethics of the Real, 18; Slavoj Žižek, The Plague of Fantasies [London: Verso, 1997]).

67. Preface, Wings of the Dove, 5.

68. Lacan, Seminar VII, 300.

69. Zupančič argues that Lacan's understanding of ethics embraces Kantian disinterestedness in the moment the individual's pursuit of desire is most pure: if, for Kant, "the ethical act is distinguished by its lack of any drive," for Lacan, "desire can be defined as the pure form of demand when all the particular objects (or 'contents') that may come to satisfy it are removed" (Ethics of the Real, 18). Badiou, too, believes that ethical consistency manifests itself as disinterested interest (Ethics, 49). 
70. Badiou, Manifesto, 71 .

71. Badiou, Infinite Thought (London: Continuum, 2004), 100, 102. Intriguingly, this is an argument Badiou makes for philosophy as well as poetry.

72. Lacan, Ethics of Psychoanalysis, 320. Lacan acknowledges that a student of his coined the phrase "l'éspace de l'entre-deux-morts" [the zone between two deaths] (Seminar VII, 320). For Lacan, characters who "live a life that is about to turn into certain death, a death lived by anticipation, a death that crosses over into the sphere of life" articulate "the indomitable power of being in the face of everything that may oppose [it]" (Seminar VII, 248, 282). Milly, like Antigone, bears witness to the implicit ethic of the desiring subject who lives between two deaths. 